\title{
Complete Manuscript Title: Viral Hepatitis B Vaccination Status of a Medical Laboratory Staff in Abidjan, Ivory Coast, West Africa
}

\author{
Agathe Dotia-Kone ${ }^{1,2}$, Timothée Ouassa ${ }^{1,2,}{ }^{,}$, Roseline Affi-Aboli ${ }^{2,3}$, Arlette Emieme ${ }^{2}$, Mathieu Kablan ${ }^{2,3}$ \\ and André Inwoley ${ }^{2,3}$
}

\author{
${ }^{1}$ Department of Bacteriology and Virology, University Félix Houphouet-Boigny, Abidjan, Ivory Coast \\ ${ }^{2}$ Department of Immunology, University Félix Houphouet-Boigny, Abidjan, Ivory Coast \\ ${ }^{3}$ Center for Diagnostic and Research on AIDS and Other Infectious Diseases, University Hospital of \\ Treichville, Abidjan, Ivory Coast
}

*Corresponding author: Timothée Ouassa, Department of Bacteriology and Virology, Faculty of Pharmacy, University Félix Houphouet-Boigny, Abidjan, Ivory Coast, Tel: (+225)-21-25-84-59

\begin{abstract}
Health care professionals working in laboratories located in Africa are supposed to deal with many potentially infectious fluids in a context of high prevalence for infectious diseases and particularly hepatitis B virus (HBV). The goal of this study was to evaluate the seroprotect ion against HBV and possible contact with the virus before vaccination in the staff of a laboratory specialized in the diagnosis of infectious diseases.
\end{abstract}

A cross-sectional study was conducted from February to March 2019 at the University Hospital of Treichville in Abidjan, Ivory Coast. It consisted in a quantitative determination of antibodies against HBV surface antigen (anti-HBs) and also in a qualitative detection of HBV surface antigen $(\mathrm{HbsAg})$ and total antibodies against HBV core antigen (anti-HBcT) by immunoenzymatic assays.

Fifty out of 59 professionals were included in the study. Anti-HBs antibodies were detected at a protective level (> $10 \mathrm{IU} / \mathrm{L})$ in 46 (92.0\%) vaccinated subjects. However, two people $(4.0 \%)$ were non-responders to vaccination against HBV. Qualitative determination of anti-HBcT antibodies showed that more 26 people included in the study (55.3\%) had previously been in contact with HBV two of whom still carrying the virus. Finally, this study made it possible to highlight the relevance of vaccination against HBV among health professionals. However, the high percentage of people displaying pre-vaccination contact with the virus without any subsequent carriage of $\mathrm{HBsAg}$ shows up the fact that the usefulness of systematic screening ( $\mathrm{HBsAg}$ and anti-HBcAb) before immunization is limited in a context of high endemicity for HBV.

\section{Keywords}

Health care workers, Laboratory, Vaccination status, Hepatitis $B$ virus

\section{Introduction}

Viral hepatitis $B(\mathrm{VHB})$ is a major public health issue in the world. Indeed, the World Health Organization (WHO) estimated to 1.75 million, people newly infected by the hepatitis B virus (HBV) worldwide in 2015 and about 257 million chronic carriers of the virus. Most deaths from viral hepatitis in 2015 were attributable to chronic liver disease $(720,000$ deaths from cirrhosis) and primary liver cancers $(470,000$ deaths from hepatocellular carcinoma) [1].

Sub-Saharan Africa, a high endemicity area for VHB is paying a heavy tribute for this disease despite the availability of an effective vaccine against HBV [2]. In Ivory Coast, the prevalence of VHB in the general population ranged from 10 to $13 \%$ according to studies conducted in the country [3-5]. It is noteworthy that $\mathrm{HBV}$ is present in all biological fluids of an infected person but especially in the blood where its concentration is high. Thus, exposure to blood is the main way of transmission of HBV which contagiousness is 10 times higher than that of the hepatitis $C$ virus and 100 times higher than that of Human Immunodeficiency Virus 
[6]. Given the risk of contact with blood and other fluids from patients, health care professionals are at high risk for VHB [7]. In fact, carriage of HBV is four to six times higher among health care workers (HCWs) than in the general population [8]. Eventually, vaccination and compliance with biosafety standard precautions remain the best methods to prevent VHB in HCWs. In Ivory Coast however, only children under 11 months are eligible for free vaccination through the Expanded Program on Immunization (EPI) implemented in the country [9]. Therefore, anti-HBV vaccination is not free of charge, neither mandatory for HCWs for which it should systematically be done [3]. Also, for people vaccinated against $\mathrm{HBV}$, but at high risk for infection, there is a need to check for the effectiveness of immunization by titration of antibodies against Hepatitis B surface antigen (anti-HBs) [10]. Among HCWs, those who are working in laboratories represent a specific population as they are supposed to deal with potentially infectious fluids in a context of high prevalence for infectious diseases and particularly HBV. For this study, we are focusing on the staff of a laboratory specialized in the diagnosis of infectious diseases in Abidjan, Ivory Coast. As part of its quality assurance policy, free immunization against HBV and other infectious diseases is provided to all the staff of this laboratory and it was useful to evaluate its immunization level.

Thus, the goal of the study was to evaluate the post-vaccination seroprotect ion of the staff against $\mathrm{HBV}$ and possible contact with the virus before vaccination.

\section{Material and Methods}

A descriptive cross-sectional study was conducted from February to March 2019 in health care workers of the Center for Diagnostic and Research on AIDS and other infectious diseases (CeDReS). This medical laboratory is located at the University Hospital of Treichville, in Abidjan, Ivory Coast and its staff is normally vaccinated against HBV (at least three doses). After obtaining informed consent from each participant, sociodemographic data, history of vaccination and possible accidental exposure to blood or other body fluids were collected. Consenting participants also provided a blood specimen which was used for quantitative detection of anti-HBs antibodies and for qualitative detection of total antibodies against hepatitis $B$ virus core antigen (anti-HBcT) and hepatitis B virus surface antigen ( $\mathrm{HBsAg}$ ).

Blood samples were obtained by venipuncture in a tube containing no additive and decanted by centrifugation at $3000 \mathrm{rpm}$ for 10 minutes. Each serum was aliquoted in a $1.8 \mathrm{~mL}$ cryovial and stored at $-20^{\circ} \mathrm{C}$ until analysis. Anti-HBs titration was performed by using a sandwich ELISA technique (MONOLISA Anti-HBs PLUS, Bio-Rad, Marnes-la-Coquette, France). HBsAg and total anti-HBc antibodies were detected by elec- tro-chemiluminescence techniques using Elecsys HBsAg II and Elecsys anti-HBc II respectively (Roche Diagnostics $\mathrm{GmbH}$, Mannheim, Germany).

The collected data was entered in the Microsoft Excel software. Statistical analysis of the results was carried out using the Statistical Package for Social Science (SPSS) software version 16.0. Proportions were compared using the Khi-Square test and significance level of the statistical tests was set at 0.05 .

\section{Results}

A total of 50 health care professionals out of 59 consented to participate in the study, leading to a participation rate of $85 \%$. Median age of the participants was 43 years (25 to 64 ) with a predominance of male (sex ratio $=1.6)$. The study population consisted mainly of laboratory technicians (40\%) and support staff (26\%). More than half of the participants $(56 \%)$ had service seniority of at least five years.

Regarding accidental exposure to blood and other body fluids, 7 (14\%) reported at least one accidental contact with blood or other body fluids during their occupational activities. Percutaneous exposure by accidental needle stick and mucous membranes exposure by blood and body fluids splashing were the most frequent types of accidental exposure with $6 \%$ of the cases (Table 1).

When considering immunization status, a majority of the participants (42) received 4 doses of hepatitis

Table 1: Characteristics of the study population.

\begin{tabular}{|l|l|l|}
\hline Parameters & n & $\%(C l)$ \\
\hline Gender & 31 & $62.0(48.6-75.5)$ \\
\hline Male & 19 & $38.0(24.6-51.5)$ \\
\hline Female & \multicolumn{2}{l|}{} \\
\hline Age range (years) & 3 & $6.0(0.0-12.6)$ \\
\hline$(20-29)$ & 15 & $30.0(17.3-42.7)$ \\
\hline$(30-39)$ & 19 & $38.0(24.6-51.5)$ \\
\hline (40-49) & 13 & $26.0(13.8-38.2)$ \\
\hline 50 and over & & \\
\hline Professional category & 12 & $24.0(12.2-35.8)$ \\
\hline Biologists & 2 & $4.0(0.00-9.4)$ \\
\hline Pharmacy interns & 3 & $6.0(0.00-12.6)$ \\
\hline Senior laboratory technicians & 20 & $40.0(26.4-53.6)$ \\
\hline Laboratory technicians & 13 & $26.0(13.8-38.2)$ \\
\hline Support Staff & & \\
\hline Seniority & 22 & $44.0(30.2-57.8)$ \\
\hline$<5$ years & 11 & $22.0(10.5-33.5)$ \\
\hline 5 to 10 years & 17 & $34.0(20.8-47.1)$ \\
\hline$>10$ years & 7 & $14.0(4.4-23.6)$ \\
\hline Blood exposure accident & 43 & $86.0(76.4-95.6)$ \\
\hline Yes & & \\
\hline No & & \\
\hline
\end{tabular}


Table 2: Vaccination status of the study population.

\begin{tabular}{|c|c|c|}
\hline Immunization status of participants & $\mathbf{n}$ & $\%(\mathrm{Cl})$ \\
\hline \multicolumn{3}{|l|}{ Number of vaccine doses received } \\
\hline 3 & 8 & $16.0(5.8-26.2)$ \\
\hline 4 & 21 & $42.0(28.3-55.7)$ \\
\hline 5 & 17 & $34.0(20.9-47.1)$ \\
\hline 6 & 4 & $8.0(0.5-15.5)$ \\
\hline \multicolumn{3}{|l|}{ Anti-HBs Antibody Rates } \\
\hline$<10 \mathrm{UI} / \mathrm{L}$ & 4 & $8.0(0.5-15.5)$ \\
\hline 10 to $100 \mathrm{UI} / \mathrm{L}$ & 7 & $14.0(4.4-23.6)$ \\
\hline 100 to $1000 \mathrm{UI} / \mathrm{L}$ & 19 & $38.0(24.6-51.5)$ \\
\hline > $1000 \mathrm{UI} / \mathrm{L}$ & 20 & $40.0(26.4-53.6)$ \\
\hline \multicolumn{3}{|l|}{ Total anti-HBc antibodies } \\
\hline Presence & 26 & $55.3(41.1-69.5)$ \\
\hline Absence & 21 & $44.7(30.5-58.9)$ \\
\hline
\end{tabular}

Table 3: Distribution of study population according to contact with HBV.

\begin{tabular}{|l|l|l|l|l|}
\hline \multicolumn{2}{|c|}{} & \multicolumn{3}{l|}{ HBs Antigen } \\
\cline { 3 - 5 } \multicolumn{2}{|c|}{} & Positive & Negative & Total \\
\hline \multirow{2}{*}{$\begin{array}{l}\text { Total Anti-HBc } \\
\text { antibodies }\end{array}$} & Positive & 2 & 24 & 26 \\
\cline { 2 - 5 } & Negative & 0 & 21 & 21 \\
\cline { 2 - 5 } & Total & 2 & 45 & 47 \\
\hline
\end{tabular}

$B$ vaccine. The average number of vaccine doses administered to staff was 4.3 and it ranged from 3 to 6 doses. Subjects who received at least 4 vaccine doses accounted for $84 \%$ of the study population. Anti-HBs antibodies were present at a protective level $(\geq 10$ $\mathrm{IU} / \mathrm{L}$ ) in 92.0 of vaccinated health care professionals. There was no significant difference between anti-HBs antibody level and the number of vaccine dose when more than 3 doses of vaccine were administered $(p=$ 0.88).

Nevertheless, $4(n=2)$ of those vaccinated were non-responders. Qualitative determination of total anti-HBc antibodies and HBsAg in the serum of the participants showed that more than half of them (53) had been in contact with the HBV (Table 2 and Table 3).

Also, it has been demonstrated HBsAg carriage in 2 participants at the time of the study.

\section{Discussion}

During this study, we evaluated the vaccination status against HBV in a population of health care professionals, combined with a quantitative determination of anti-HBs antibodies which are the markers of immunization against HBV. A pre-vaccination contact with HBV and an asymptomatic carriage of the virus were also assessed by determining total anti-HBc antibodies and $\mathrm{HbsAg}$ respectively. From our results, it appears that the majority $(84 \%)$ of the staff received at least 4 doses of hepatitis $B$ vaccine according to the current vaccination schedule in Ivory Coast. As expected, immunization coverage was higher in this laboratory than those reported at a national level which was estimated to 24.7 [3]. It was also higher than those of studies conducted in South African [11] and Pakistan [12] studies, which reported vaccine coverage against HBV of $72.5 \%$ and $73.4 \%$, respectively among the health staff surveyed. In France, vaccination coverage against HBV increased from $44 \%$ in 1989 [13] to nearly $91.7 \%$ in 2009 [14] among health care staff. However, WHO-recommended $\mathrm{HBV}$ vaccination for health professionals remains poorly implemented in Côte d'Ivoire because no legal or regulatory provisions makes it mandatory.

Anti-HBs antibodies were found at a protective level (> $10 \mathrm{IU} / \mathrm{L}$ ) in $92.0 \%$ of vaccines. This level of immunization is higher than the $78.0 \%$ reported by Dorkenoo, and collaborating with health care workers in Lomé [15].

According to the WHO, a series of three doses of the vaccine induce protective levels of anti-HBs antibodies in more than $95 \%$ of healthy infants, children and young adults (WHO, 2012). However, normally vaccinated subjects in our study population were not immunized by vaccination. This points to the need to monitor the effectiveness of HBV vaccination by quantifying anti-HBs antibodies for possible vaccine recalls that will induce immunization.

Anti-HBc antibodies were present in $55.3 \%$ of vaccinated subjects in our study. The presence at a high level high of this marker in our study population could be explained by a context of high endemicity for HBV, where the majority of adults have already been in contact with HBV [16], and are therefore carriers of anti-HBc antibodies.

Similarly, more than half of the vaccinated participants $(51.1 \%)$ were carriers not only of anti-HBc antibodies, a marker for natural contact with HBV but also of anti-HBs antibodies at titers greater than 10 IU/L. This result highlights the difficulty in a highly endemic context to screen routinely a prior contact with HBV before vaccination as recommended by some authors [17]. This is why, in Ivory Coast, vaccination against $\mathrm{HBV}$ is implemented on the sole basis of the absence of $\mathrm{HBsAg}$, or even without the detection of any HBV marker. It could also be useful to detect the level of anti-HBs antibodies in people harboring total anti-HBc antibodies and without any history of anti-HBV vaccination. Therefore, the proportion of those who were naturally cured and immunized after HBV infection could be estimated. Finally, the result of such study could provide data supporting or not the need of systematic detection of HBV in a context of their inaccessibility in many areas of the country. Indeed, the low availability of screening tests could be explained not only by the concentration of laboratories in the main city, but also by the relatively high cost of these analysis [18]. 


\section{Conclusion}

Preventing the risk of HBV infection in health professionals through vaccination is one of the WHO's recommendations. Although the implementation of this recommendation is not yet effective in Ivory Coast, vaccination coverage can be high in some specific departments. Thus, this study has documented the immunization status of a laboratory staff working in a laboratory of a teaching hospital vis-a-visviral hepatitis $B$. It has also shed light on the relevance of vaccination against HBV among health care professionals. However, the high rate of people showing prior contact with the virus questioned the need for systematic screening of $\mathrm{HbsAg}$ and anti-HbcAb before any immunization policy.

\section{Sources of Support}

Not applicable.

\section{Acknowledgments}

The authors want to acknowledge Dr. Toni from the Integrated Center for Bio clinical Research of Abidjan (CIRBA) for allowing to perform some of the experiments, Pr. Menan, Head off the Center for Diagnostic for AIDS and other infectious diseases (CeDReS) and all the participants of the study.

\section{References}

1. World Health Organization (2017) Summary: Weekly epidemiological record, NO 27, 7.

2. Pourette D, Enel C (2014) Représentations et vécu de I'hépatite $B$ de patients subsahariens en Côte d'Ivoire et en France. Santé publique 26: 869-878.

3. Assi C, Allah-Kouadio E, Ouattara A, Diakité M, Koné S, et al. (2011) Couverture vaccinale contre l'hépatite virale $B$ et prévalence de l'antigène HBs dans une profession à risque : Etude transversale portant sur 244 sapeurs-pompiers de la ville d'Abidjan. J Afr Hépatol Gastroentérol 5: 115118.

4. Kouassi-M'Bengue A, Nassirou F, Doumbia M, Folquet-Amorissani M (2012) Prevalence of viral hepatitis B in children under 5 years in Côte d'Ivoire. $30^{\text {th }}$ Annual Meeting in Advances in Paediatric Infectious Diseases, Grèece.

5. Séri BL (2012) Prévalence, incidence et facteurs associés des infections par les virus du $\mathrm{VIH}$, de l'hépatite $\mathrm{B}$ et de l'hépatite $C$ chez les donneurs de sang. Analyse de la base de données du Centre National de Transfusion Sanguine (CNTS) d'Abidjan, 1992-2012.

6. Van Herck K, Vorsters A, Van Damme P (2008) Prevention of viral hepatitis ( $B$ and $C$ ) reassessed. Best Pract Res Clin Gastroenterol 22: 1009-1029.

7. Sharma R, Rasania SK, Verma A, Singh S (2010) Saudan: Study of prevalence and response to needle stick injuries among health care workers in a tertiary care hospital in Delhi, India. Ind J Comm Med 35: 74-77.

8. Alavian SM, Izadi M, Zare AA, Lankarani MM, Assari S, et al. (2008) Survey of the level of anti-HBs antibody titer in vaccinated Iranian general dentists. Spec Care Dentist 28: 265-270.

9. Aka LBN, Brou AN, Noufe S (2012) Politique vaccinale contre l'hépatite virale $B$ dans le cadre du Programme Élargi de Vaccination (PEV) en Côte d'Ivoire: Difficultés rencontrées. R Hepavir 5: 17.

10. World Health Organization (2017) World report on hepatitis, executive summary WHO/HIV/2017.

11. Burnetta RJ, Guido F, Mphahlele MJ, Mureithi JG, Africa PN, et al. (2011) Hepatitis B vaccination coverage in healthcare workers in Gauteng Province, South Africa. Vaccine 29: 4293-4297.

12. Attaullah S, Khan S, Naseemullah, Ayaz S, Khan SN, et al. (2011) Prevalence of HBV and HBV vaccination coverage in health care workers of tertiary hospitals of Peshawar, Pakistan. Virol J 8: 275

13. Houdart $P$ (1989) Hépatite $B$, deux médecins sur trois en danger. Impact Med 24-26.

14. Guthman JP, Fonteneau L, Ciotti C, Bouvet E, Pellissier G, et al. (2012) Vaccination coverage of health care personnel working in health care facilities in France: Results of a national survey, 2009. Vaccine 30: 4648-4654.

15. Dorkenoo AM, Kolou M, Sawadogo H, Fétéké L, Agbenu E, et al. (2014) Évaluation de la protection vaccinale contre le virus de l'hépatite $B$ chez le personnel soignant hospitalier à Lomé Médecine et Santé Tropicales 24: 266-270.

16. World Health Organization (2018) Hépatite virale B données.

17. Lu CY, Ni YH, Chiang BL, Chen PJ, Chang MH, et al. (2008) Humoral and cellular immune responses to a Hepatitis $B$ vaccine booster $15-18$ years after neonatal immunization. $J$ Infect Dis 197: 1419-1426.

18. World Health Organization (2009) Relevé épidémiologique hebdomadaire de l'Organisation Mondiale de la Santé, 2 octobre N840: 405-420. 